\title{
Effects of Financial Crisis on Capital Structure of Listed Firms in Vietnam
}

\author{
Truong Hong Trinh ${ }^{1} \&$ Nguyen Thao Phuong ${ }^{1}$ \\ ${ }^{1}$ University of Economics, The University of Danang, Vietnam \\ Correspondence: Truong Hong Trinh, Faculty of Finance, University of Economics, Danang City, Vietnam. Tel: \\ 84-511-352-5459. E-mail: trinh.th@due.edu.vn
}

Received: November 14, 2015

Accepted: December 3, $2015 \quad$ Online Published: December 21, 2015

doi:10.5430/ijfr.v7n1p66

URL: http://dx.doi.org/10.5430/ijfr.v7n1p66

\begin{abstract}
This paper investigates effects of financial crisis on capital structure of listed firms in Vietnam. Regression models on the relation between the leverage and firm size, growth, profitability, tangibility, together with crisis dummies is built based on a sample of 265 firms listed on HNX and HOSE for the period of 2006-2013. The empirical result indicates that firm size, profitability, and tangibility have statistically significant impacts on capital structure. The growth is not statistically significant in explaining the variance of the leverage. The study result also reveals that capital structure of Vietnamese listed firms has not changed significantly under the financial crisis.
\end{abstract}

Keywords: capital structure, leverage, financial crisis, Vietnam

\section{Introduction}

Half a century ago, the first paper on capital structure of Modigliani and Miller (1958) stated that the capital structure of firms has no effect on the firms' value. Modigliani and Miller's argument is based on several assumptions, which make the financial market to be perfect and thus not consistent with the real market. In fact, the global financial crisis (GFC) bursts out in 2008, many firms faced difficulties related to capital structure that influenced their value (Zarebski \& Dimovski, 2012). Thus, a big question is that how does the financial crisis affect capital structure?

Effects of the global financial crisis was different among countries due to the different level of development in the financial market, the policies of government and the sensitivity of that country to external incidents. The financial crisis in 2008 had three basic impacts on the economy of Vietnam. Firstly, demand power shrinks down due to a strong decrease on supplies as well as the income sources, and economic growth depends on export that account for 60\%-70\% GDP. Secondly, the Foreign Direct Investment (FDI) decreases in both quantity and size, which affect the domestic businesses that depend on this fund. Lastly, the financial market was also strongly affected. Freezing investing activities and fluctuating interest rate made the financial market unpredictable and raised many difficulties for investors as well as borrowers. In such situation, the question is that Vietnamese firms change their capital structure during the financial crisis or not?

In order to find the answer for the above question, this paper investigates the effects of the recent financial crisis on the capital structure of listed firms in Vietnam, and the significance of those determinants changes in capital structure (leverage ratio). Regression models is built for relations between the leverage and firm size, growth, profitability, tangibility, together with crisis dummies for the period of 2006-2013. The empirical result provides an important understanding on characteristics of Vietnamese listed firms in response to the financial crisis.

\section{Literature Review}

\subsection{Theories of Capital Structure}

In the first discussion about the capital structure, Modigliani and Miller (1958) showed that the capital structure had no impact on the value of the firm, with an assumption of a perfect capital market (that is a market with no transaction costs, no taxes and asymmetric information, no bankruptcy cost, no agency cost, full competition and no arbitrage opportunities). However, since the perfect capital market cannot be obtained in reality, Modigliani and Miller (1963) added corporate taxes into their model and found that the firm value increase when the leverage increases, due to the tax-deductibility of debt. Miller (1977) himself added personal taxes and pointed that the income from debt, which is generally interest, is taxed as personal income, while the income from stocks (generally 
the dividends and capital gains) is taxed at a lower rate and the tax of capital gains can be deferred until the stock is sold. Therefore, he concluded that the deductibility of interest favors the use of debt financing, but the more favorable tax treatment of income from stock favors the use of equity financing.

The trade-off theory was established by Kraus and Litzenberger (1973). The trade-off model identifies the optimal financial leverage in the trade-off between the benefits from high debt and the business risks, as Myers (1984) said: "In the static trade-off theory, optimal capital structure is reached when the tax advantage to borrowing is balanced, at the margin, by cost of financial distress." Contrary with the trade-off theory, which produce an optimal level of debt where the benefit of the last dollar of debt just offsets the cost of bankruptcy, the pecking order theory, developed by Myers (1984) and Myers and Majluf (1984), rejects any optimal debt ratio and indicates an order of sources of financing depends on the cost of such sources. Thus, the internal source (retained earnings) is the first on the list, which is basically "free" to the firm. When the firm has to use external funds, the low-risk debt is preferred to the equity, which is high-risk and thus high-cost. Jensen and Meckling (1976) first introduced the concept of agency costs in a financial economic context. They highlighted that agency costs arise in any situation involving cooperative effort. In addition, they argued that financing decisions are determined by the extent of conflict between firm insiders and firm outsiders. The agency cost theory states that optimal capital structure depends on the ability to minimize the resulting agency cost originating in this conflict.

\subsection{Determinants of Capital Structure}

There are numerous papers about the factors that affect the capital structure (the debt ratio or the leverage). The main determinants of capital structure discussed are growth opportunities, profitability, firm size, tangibility, and other factors.

Size: The agency theory indicates a positive relation between size and agency cost, in which large firms have more agency costs than small firms (Jensen \& Meckling, 1976). When firms issue debt, managers are more monitored by outsiders (Ibrahimo \& Barros, 2009). It is difficult for managers to aim their own goals, and the agency problem is less. Therefore, the agency theory suggests also a positive relation between size and leverage. Rajan and Zingales (1995) indicates that the size is positive ralated to capital structure, but Ferri and Jones (1979) suggests that the size has no a positive impact on capital structure. While Kim and Sorensen (1986) reveal that there is not a relation at all, the firm size is uncorrelated with capital structure, Timan and Wessels (1998) conclude that there is a relation between size and capital structure. In addition, Deesomsak, Paudyal, and Pescetto (2004) find that firm size, non-debt tax shield and liquidity are significant factors in capital structure decisions in the East Asian financial crisis of 1997.

Growth: There is a negative relation between growing firms and leverage (Rajan \& Zingales, 1995; Titman \& Wessels, 1988). This result is supported by pecking order theory, in which the references to finance a new investments is with internal funds. According to agency theory, managers have a preference to satisfied first their own goal; maximize their utility, and second that of the stakeholders (Jensen \& Meckling, 1976; Titman \& Wessels, 1988). Thus, it suggests a positive relation between growth and leverage. The growth opportunities can be linked with the financial crisis. Baily and Elliott (2009) suggests that there is less or no growth for several quarters during the financial crisis period.

Profitability: Profitability influences the capital structure, which is often discussed by different theories and researchers. Ozkan (2001) suggest a negative relation between profitability and leverage, what is explained by the pecking order theory. The pecking order theory suggests that firms prefer to finance with internal funds over outside finance (Myers, 1984). Empirical studies of Rajan and Zingales (1995) and Titman and Wessels (1988) report that the influence of profitability in the United States on leverage is most of the time negative related. In addition, financial crisis has influence on economic growth and stock market, which firms' profitability relies on market demand and stock market.

Tangibility: The choice of the type of the firm's assets affects the capital structure. Myers and Majluf (1984) suggest that costs are related with issuing debt due to the information asymmetry problem; managers are more informed than the outside shareholders. These costs can avoid by issuing debt secured by collateral, because the value is known of the collateral. Therefore, when firms have the opportunity to take this advantage to use assets as collateral, it may be expected that these firms issue more debt (Myers \& Majluf, 1984). The empirical part of the research of Rajan and Zingales (1995) and Titman and Wessels (1988) concludes a positive relation between tangibility and leverage. Myers and Majluf (1984) also demonstrate a positive relation. In addition, banks suggested with a liquidity and credit risks during financial crisis. Thus, they required more security when they issue loans to firms (Berg \& Kirschenmann, 2010). 
Crisis: The recent financial crisis that started at the end of year 2007 in the subprime credit market led to a liquidity crisis in the short-term money markets. Many earlier studies argue that credit supply conditions are an important factor in firms' financing decisions.

Voutsinas and Werner (2011) find that extreme credit supply fluctuations in Japan (asset bubble burst in 1989 and banking crises in 1998) had a significant impact on Japanese firms' capital structure. They find that a decrease in the supply of credit will affect negatively firm's leverage ratios. Balsari and Kirkulak (2008) examine the effects of major financial crisis on capital structure of firms that happened in the Turkish economy in 1994 and 2001-02. Their findings suggest that a negative impact of 1994 crisis on the leverage ratio. The studies of Pattani and Vera (2011) and Akbar, Rehman, and Ormrod (2013) are given the same result during 2007-2009 financial crisis, in which UK firms held more cash and issue more equity.

In contrast, Lim (2004) finds that large Korean firms left the financial intermediaries and turned to capital markets after the Korean crisis. This was not the case for profitable small firms which were gaining easier access from the financial intermediaries after the crisis. Fosberg (2012) reports that global equity issuance declined during 2007-2008 with the data provided by Wall Street Journal. However this trend was reversed in 2009 and continued in 2010. A similar trend was observed for debt issuance. The global debt/equity issuance ratio increased in 2008 and then decreased gradually towards the end of 2010.

Table 1. Determinants of capital structure

\begin{tabular}{lll}
\hline Determinants & Predicted sign by theories & Previous empirical evidence \\
\hline Size & + (Agency theory) & $\begin{array}{l}\text { Rajan and Zingales (1995), Titman and Wessels, (1988), } \\
\text { Jensen and Meckling (1976), Ibrahimo and Barros (2009) }\end{array}$ \\
\hline \multirow{2}{*}{ Growth } & - (Pecking order theory) & Rajan and Zingales, (1995), Titman and Wessels, (1988) \\
\cline { 2 - 3 } & + (Agency theory) & Jensen and Meckling (1976), Titman and Wessels, (1988) \\
\hline Profitability & - (Pecking order theory) & Rajan and Zingales, (1995), Titman and Wessels, (1988) \\
\hline Tangibility & + (Signaling theory) & $\begin{array}{l}\text { Rajan and Zingales, (1995), Titman and Wessels, (1988), } \\
\text { Myers and Majluf, (1984) }\end{array}$ \\
\hline \multirow{2}{*}{ Crisis } & + & Lim (2004), Fosberg (2012) \\
& - & $\begin{array}{l}\text { Voutsinas and Werner (2011), Balsari and Kirkulak.(2008), } \\
\text { Pattani and Vera (2011), Akbar et al. (2013) }\end{array}$ \\
\hline
\end{tabular}

\section{Data and Methodology}

\subsection{Data}

The data is collected from financial statements of listed firms in the period of 2006-2013. Firms in financial sector are eliminated from initial sample of 927 listed firms on HOSE and HNX in Vietnam. The study chooses 265 listed firms which have financial statements during 2006-2013. Table 2 shows descriptive statistics of regression variables.

Table 2. Descriptive statistics of regression variables

\begin{tabular}{lllll}
\hline & Min & Max & Mean & Std. Dev. \\
\hline Leverage & 0.003 & 0.978 & 0.500 & 0.221 \\
\hline Size & 8.386 & 18.143 & 12.989 & 1.364 \\
\hline Growth & -0.990 & 30.101 & 0.268 & 1.244 \\
\hline Profitability & -0.646 & 0.627 & 0.071 & 0.082 \\
\hline Tangibility & 0.000 & 0.939 & 0.265 & 0.198 \\
\hline
\end{tabular}

Table 2 shows that the leverage of the sample firms range from $0.3 \%$ to $97.8 \%$, with the average of about $50 \%$. It 
seems that listed firms in Vietnam have no preference on which source should be used to finance: debt or equity. The size ranges from 8.386 to 18.143 , with the average of 12.989 . The growth ranges from $-99.74 \%$ to $3010.1 \%$, with the average of $26.754 \%$, indicates that the growth opportunities varies much among firms. Profitability (ROA) ranges from $-64.6 \%$ to $62.7 \%$, with the average of $7.15 \%$. Tangibility ranges from 0 to 0.939 , with the average of 0.265 .

Table 3. The mean and standard deviation of the variables

\begin{tabular}{lllllllll}
\hline $\begin{array}{l}\text { Mean } \\
\text { Std. }\end{array}$ & 2013 & 2012 & 2011 & 2010 & 2009 & 2008 & 2007 & 2006 \\
\hline Leverage & 0.504 & 0.499 & 0.502 & 0.484 & 0.491 & 0.470 & 0.476 & 0.568 \\
& 0.217 & 0.221 & 0.215 & 0.211 & 0.213 & 0.227 & 0.218 & 0.232 \\
\hline Size & 13.398 & 13.345 & 13.322 & 13.205 & 13.023 & 12.805 & 12.641 & 12.156 \\
& 1.434 & 1.401 & 1.356 & 1.323 & 1.274 & 1.242 & 1.222 & 1.204 \\
\hline Growth & 0.344 & 0.022 & 0.150 & 0.331 & 0.264 & 0.259 & 0.572 & N/A \\
& 2.683 & 0.468 & 0.387 & 0.687 & 0.810 & 0.478 & 1.512 & N/A \\
\hline Profitability & 0.043 & 0.046 & 0.064 & 0.083 & 0.092 & 0.073 & 0.091 & 0.089 \\
& 0.075 & 0.087 & 0.079 & 0.067 & 0.075 & 0.079 & 0.064 & 0.103 \\
\hline Tangibility & 0.254 & 0.265 & 0.263 & 0.269 & 0.274 & 0.285 & 0.249 & 0.264 \\
& 0.201 & 0.200 & 0.201 & 0.205 & 0.200 & 0.200 & 0.184 & 0.189 \\
\hline
\end{tabular}

The mean leverage of firms declined dramatically in 2007. In fact, there was an issue in the market that forced managers to adjust their capital structure: borrow less and depend more on equity. It notes that there had been already a shortage of credit in the market before financial crisis, and that might be the reason for this fall. At the end of 2010, the leverage increased together with the recovery of the economy, although it could not reach the level of $56.8 \%$ at 2007.

The size of firms gradually increases over the period, together with the increase in its variation. Inflation rate is higher in the financial crisis that might be a reason for a high value of assets, which is used as a proxy of size in this research. Overtime firms also have to expand, so its size should increase also. The mean growth is not stable overtime, and its range of fluctuation is quite wide that makes it difficult to assess the trend. The mean profitability is high in the time of crisis compare to the other time. The ratio of fixed assets and total assets is approximately the same in the whole period, and is a little bit higher in crisis period.

\subsection{Methodology}

The techniques are used to test the conditions of a regression model including autocorrelation, multicollinearity, and distributions. Durbin-Watson test is used to detect the autocorrelation. Multicollinearity is tested by a Variance Inflation Factor (VIF) test. The distribution of the variables is assessed through the histograms and skewness tests. The correlation coefficient is found on the leverage of each firm throughout a period from 2006 to 2013. The correlation coefficients are also tested in two different periods: pre-crisis to crisis and crisis to post-crisis to make clear about how the leverage adjusted during those periods.

The impact of the financial crisis on the firms' leverage is examined through panel data regression models. Panel data sets are generally characterized by a sample of units observed over a number of periods allowing researchers to apply more complex models than the ones used in cross-sectional or time series analysis. The most common panel data estimation techniques are the fixed effects model (FEM) and the random effects model (REM). This study includes the dummy variables for crisis period, hence the REM is considered to be the most suitable technique to solve the research question about the impact of financial crisis on capital structure.

In this regression, the independent variables are the size (measured by the natural logarithm of total assets), growth opportunities (measures by the percentage change of total assets), profitability (measured by ROA - return on assets) and tangibility (measured by the ratio between fixed assets and total assets). Observations are taken in each year for the whole sample to identify the regression line. The observations which have leverage ratio equal to 0 or greater 
than 1 is eliminated because it is considered impossible in reality, thus it is a mistake in typing in data.

A regression model will be obtained by OLS method, in form:

Model 1:

$$
\text { Lev }_{i, t}=\beta_{0}+\beta_{1} \text { Size }_{i, t}+\beta_{2} \text { Growth }_{, t}+\beta_{3} \text { ROA }_{, t}+\beta_{4} \text { Tang }_{i, t}+e_{i, t}
$$

Models of 2, 3, 4, and 5 include a dummy variable in each which describes the crisis period:

$$
\begin{gathered}
\text { Lev }_{i, t}=\beta_{0}+\beta_{1} \text { Size }_{i, t}+\beta_{2} \text { Growth }_{i, t}+\beta_{3} \text { ROA }_{t, t}+\beta_{4} \text { Tang }_{i, t}+\beta_{5} D C_{i, t}+e_{i, t} \\
\text { Lev }_{i, t}=\beta_{0}+\beta_{1} \text { Size }_{i, t}+\beta_{2} \text { Growth }_{i, t}+\beta_{3} \text { ROA }_{i, t}+\beta_{4} \text { Tang }_{i, t}+\beta_{5} D C 2_{i, t}+e_{i, t} \\
\text { Lev }_{i, t}=\beta_{0}+\beta_{1} \text { Size }_{i, t}+\beta_{2} \text { Growth hit, }_{h}+\beta_{3} \text { ROA }_{i, t}+\beta_{4} \text { Tang }_{i, t}+\beta_{5} D C 3_{i, t}+e_{i, t} \\
\text { Lev }_{i, t}=\beta_{0}+\beta_{1} \text { Size }_{i, t}+\beta_{2} \text { Growth }_{i, t}+\beta_{3} \text { ROA }_{i, t}+\beta_{4} \text { Tang }_{i, t}+\beta_{5} D C C_{i, t}+e_{i, t}
\end{gathered}
$$

Table 4. Description of variables in regression models

\begin{tabular}{lll}
\hline Variable description & Notation & Formula \\
\hline The leverage ratio of the firm & Lev & $\frac{\text { Total debts }}{\text { Total assets }}$ \\
\hline The size of the firm & Size & $\ln$ (Total assets) \\
\hline The growth opportunity of the firm & Growth & Percentage change of Total assets \\
\hline The profitability of the firm & ROA & $\frac{\text { Net income }}{\text { Total assets }} \times 100 \%$ \\
\hline The tangibility of the firm & Tang & $\frac{\text { Fixed assets }}{\text { Total assets }}$ \\
\hline
\end{tabular}

There was a lag time for financial crisis influence in some countries as the case of Vietnam. Since the definition of a crisis period in Vietnam is still unclear, it is necessary to compare the three different periods to identify which period has the most influence on the model. The dummy crisis variable is added in models of 2, 3, 4, and 5 that represent different period of crisis. The variable DC1 takes the crisis period to be 2007-2008, when it takes value of 1 and 0 otherwise. Similarly, the variable DC2 takes the crisis period of 2008-2009, the variable DC3 takes the crisis period of 2009-2010 and the variable DC4 takes the crisis period of 2010-2011. The four models are then compared to identify the crisis period.

In order to investigate how firms adjust their leverage between each period, the study also substitute the crisis dummy variable with two new dummy variables which will define three periods: the pre-crisis dummy (DCPR) that takes value of 1 for years before the crisis period and 0 otherwise; and the post-crisis dummy (DCPO) that takes value of 1 for years after the crisis period and 0 otherwise. Hence the sixth model is as follow:

Model 6:

$$
\text { Lev }_{i, t}=\beta_{0}+\beta_{1} \text { Size }_{i, t}+\beta_{2} \text { Growth }_{i, t}+\beta_{3} \text { ROA }_{i, t}+\beta_{4} \text { Tang }_{i, t}+\beta_{5} D C P R_{i, t}+\beta_{6} D C P O_{i, t}+e_{i, t}
$$

\section{Empirical Results and Discussion}

\subsection{Empirical Results}

In order to identify the right crisis period, four regression models of 2, 3, 4, and 5 is evaluated through crisis dummy variables. From regression results as in Table 5, model 4 has the highest value of $\mathrm{R}$ square as well as adjusted $\mathrm{R}$ square. The crisis dummy variable is also significant at $1 \%$ level in model 4 . Therefore, it concludes that the crisis period of Vietnam is the period of 2009-2010. Multicollinearity is tested through the VIF statistics. All VIF values are approximately 1 , less than 5 , so there is no collinearity in the models. 
Table 5. Regression results for models of 2, 3, 4, 5

\begin{tabular}{lllll}
\hline & $\begin{array}{l}\text { Model 2 } \\
(07-08)\end{array}$ & $\begin{array}{l}\text { Model 3 } \\
(08-09)\end{array}$ & $\begin{array}{l}\text { Model 4 } \\
(09-10)\end{array}$ & $\begin{array}{l}\text { Model 5 } \\
(10-11)\end{array}$ \\
\hline C & -0.024 & -0.015 & -0.006 & -0.002 \\
\hline Size & $0.047^{* *}$ & $0.046^{* *}$ & $0.045^{* *}$ & $0.045^{* *}$ \\
\hline Growth & 0.000 & 0.001 & 0.001 & 0.001 \\
\hline ROA & $-1.168^{* *}$ & $-1.169^{* *}$ & $-1.177^{* *}$ & $-1.156^{* *}$ \\
\hline Tang & $-0.081^{* *}$ & $-0.082^{* *}$ & $-0.081^{* *}$ & $-0.080^{* *}$ \\
\hline DC1 & $0.022^{*}$ & & & 0.001 \\
\hline DC2 & & $0.022^{*}$ & $0.026^{* *}$ & 0.262 \\
\hline DC3 & & & 0.260 \\
\hline DC4 & & 0.264 & 0.263 & 0.262 \\
\hline R2 & 0.264 & 0.262 & & \\
\hline Adjusted R2 & & 0.06 & \\
\hline
\end{tabular}

**. Coefficient is significant at the 0.01 level (2-tailed).

*. Coefficient is significant at the 0.05 level (2-tailed).

In order to investigate how the firm change the leverage during 2006-2013, the study conducts three models of 1 , 4, and 6. Model 1 has no dummy crisis; model 4 stands for the model with the dummy variable of crisis period; model 6 has two dummy variables of pre-crisis period and post-crisis period.

Table 6. Regression results for models of $1,4,6$

\begin{tabular}{llll}
\hline & Model 1 & Model 4 & Model 6 \\
\hline C & -0.002 & -0.006 & -0.013 \\
\hline Size & $0.045^{* *}$ & $0.045^{* *}$ & $0.048^{* *}$ \\
\hline Growth & 0.001 & 0.001 & 0.000 \\
\hline ROA & $-1.155^{* *}$ & $-1.177^{* *}$ & $-1.201 * *$ \\
\hline Tang & $-0.080^{* *}$ & $-0.081^{* *}$ & $-0.083^{* *}$ \\
\hline DC3 & & $0.026^{* *}$ & 0.002 \\
\hline DCPR & & & $-0.038^{* *}$ \\
\hline DCPO & & & 0.269 \\
\hline R2 & 0.262 & 0.265 & 0.267 \\
\hline Adjusted R2 & 0.261 & 0.263 & \\
\hline
\end{tabular}

**. Coefficient is significant at the 0.01 level (2-tailed).

*. Coefficient is significant at the 0.05 level (2-tailed).

The impact of size, growth, profitability, and tangibility on the leverage is showed in Table 6. Size is significantly correlated with the leverage. Its positive sign indicates that larger firms tend to borrow more. The growth does not have explanatory power in the models, since its correlation with the leverage is not significant in all equations. Return on assets and the ratio of fixed assets to total assets have negative signs in their coefficients, and both variables are significant in these models. The negative sign in the profitability shows that companies which are better in generating profit can borrow debt more easily, while the negative sign in tangibility indicates that firms with less fixed assets tends to use more debt in their financing. Except for the growth and the tangibility, all other results coincide with previous studies and expectations. 
Table 6 also shows the impact of dummy variables on the leverage. Model 6 has a higher adjusted R-Square than model 4, shows that substituting the crisis dummy variable by these two new ones helps to describe more the variance in the leverage. In this model, the dummy variable DCPO are negatively significant at level of 0.01 . It means that the capital structure of Vietnamese firms significantly lower than the other period. However, the study also found that the mean leverage tends to increase after the crisis, though it cannot reach the level of the years before the crisis. Therefore, this negative impact implies the consequence of the crisis continues in later years, and makes the leverage to be lower than what it should be. In other word, if the consequence of the financial crisis is totally diminished, the level of debt will be recovered fully to what it was. The dummy variable of pre-crisis (DCPR) is not significant in this model, indicates that there is no different in the leverage between the two period: pre-crisis and crisis. This result is questionable since it is shown above that the leverage of firms significantly fall in the crisis period. One possible explanation for this is that this decrease not only due to the financial crisis itself, but also is mostly caused by the changes in other firms' factors (such as profitability and tangibility).

\subsection{Discussion on the Results}

The size has statistically positive impact on the leverage in all three models of 1,4 , and 6 . The coefficient values are $0.045,0.045$ and 0.048 respectively. This is consistent with most of previous literature predictions and empirical results. Based on Titman and Wessels (1988) argument, large firms primarily have lower cost of bankruptcy and thus an easily access to low-cost debt, which supports the trade-off theory. In crisis period, as there is more chance that companies will go bankrupt, banks are more careful to give credit for firms. The size of the firms is then an important factor that banks consider to make their decision. Larger firms' reputation and their low business risk make banks feel safe to give credit.

The growth has no relation to the leverage. This result is contract with many previous studies that is supported both agency theory and trade-off theory. The agent for shareholders - managers - often chooses to invest in risky projects to increase return for shareholders. This makes the creditors unwilling to give credit unless they are offered an additional risk premium - a compensation for their additional risk. Because of the extra cost of debt, growing firms are less likely to use debt, and use equity instead (trade-off theory). Pecking order theory also supports this relation by providing that growing firms have more internal financial sources to use, so this source will be prioritized. On the other hand, a growing firm is also more reliable to banks, that they can be offered more debt, so a positive sign in the relation between growth and leverage is also possible. This empirical study implies that managers do not take the growth into account when making decision about the capital structure in Vietnam

The profitability has a statistically negative relation to the leverage. This empirical result is also coincides with previous studies. The coefficients of this variable are negative, indicates that firms with high profitability tend to borrow less. This relation is supported by pecking order theory, which tells that firms will prioritize the internal funds before seeking for other sources. Firms with high profitability will then use their earning first to finance, thus reduce the proportion of debt in their capital structure. This trend is strengthening during crisis period because of the inaccessible of external debt. Together with the difficulties in issuing debts, just a slightly higher profitability can strongly influence the debt level in the companies, that managers will depend on this source to help their business overcome the bad conditions.

The empirical study found no evidence to claim that the leverage of Vietnamese firms change during and after the financial crisis. The crisis in fact made the leverage of most firms to go down, but in recent years it has recovered, although not completely. This result can be explained that the financial market in Vietnam has not integrated much into the global market, so the influences from the financial crisis started in the US market on the financial market in Vietnam is indirect: through the changes in supplies and demands in other aspects of the economy, as well as the decrease in import and export activities. Before and after the financial crisis, the government in Vietnam still takes the control over the economy. With some strict monetary policies and fiscal policies to maintain a low rate of inflation and keep the rate of development, the financial system is also well controlled by the government, and the State Bank still has control over all commercial banks in Vietnam. This makes it easier for the government to deal with the problems arise from the crisis.

However, the financial crisis has had an impact on the activities of the whole economy, especially companies listed on the stock markets. Managers are aware of the bad conditions that the economy was facing, so they are more sensitive to even a tiny change outside. Consider that the capital structure decisions are important for the companies to overcome the bad period, managers are more careful to choose which sources to finance. In crisis period, credit from banks are limited and very difficult to access, so the quality of companies is assessed more carefully, through the size, profitability and the ability to payback debt. This assessment affects much on the ability to finance with debt 
of firms, thus affects the leverage of firms. In addition, the higher leverage before the crisis period, the leverage of firms on average is higher, proves that companies can easily be given credit by banks. However, the declining in the leverage when the crisis burst out continues although there are some signs of recovery in the economy. This partly due to the fact that the demand for credit is still low, inventories are still high that firms are still in high risk, while some firms with the need to borrow do not have stable financial conditions to meet the requirements for credit.

\section{Conclusion}

This paper has investigated the effects of the financial crisis on the capital structure with the size, growth, profitability and tangibility as determinants. The empirical results suggest that there is a positive relation between firm size and leverage because large firm are probably more diversified and less likely to go bankrupt. Since it is safer for creditors to lend to large firms, size becomes also more important in relation to the leverage during the crisis. Profitability is negative related to leverage. An argument for this relation is that firms prefer to finance with internal funds over outside finance to avoid asymmetric costs. During the crisis, profitability is more important associated with the leverage because of the lack of available credit from banks. Tangibility has a negative relation on leverage. Although tangible assets can secure the debt as collateral, they also reduce the liquidity of the firms, which is more important in crisis period.

The study result also reveals that growth has no significant relation to the leverage in empirical models. There is also no evidence to claim that the leverage of Vietnamese listed firm significantly change during the crisis period. These findings provide empirical evidence on relation of the leverage with growth and crisis. Vietnamese managers have less constraint from shareholders. The growth does not take into account when Vietnamese firms make decisions on capital structure. In addition, financial market in Vietnam has not much integrated into the global market, and the financial system is well controlled by government, the leverage of Vietnamese listed firm has no significantly change during the crisis period.

\section{References}

Akbar, S., Rehman, S., \& Ormrod, P. (2013). The impact of recent financial shocks on the financing and investment policies of UK private firms. International Review of Financial Analysis, 26, 59-70. http://dx.doi.org/10.1016/j.irfa.2012.05.004

Baily, M. N., \& Elliott, D. J. (2009). The US financial and economic crisis: Where does it stand and where do we go from here. Brookings Institution. Retrieved July 28, 2015, from http://www.brookings.edu/research/papers/2009/06/15-economic-crisis-baily-elliott

Balsari, C. K., \& Kirkulak, B. (2008). Effect of financial crises on the capital structure choice: Evidence from Istanbul Stock Exchange (ISE). 5th Conference of the Portuguese Finance Network Proceedings. Combria, Portugal.

Berg, G., \& Kirschenmann, K. (2010). The impact of the US financial crisis on credit availability for small firms in Central Asia. Retrieved from http://www.rug.nl/research/globalisation-studies-groningen/research/conferencesandseminars/conferences/eumi crofinconf2011/papers/2a.kirschenmann-berg.pdf

Deesomsak, R., Paudyal, K., \& Pescetto, G. (2004). The determinants of capital structure: evidence from the Asia Pacific region. Journal of Multinational Financial Management, 14(4), 387-405. http://dx.doi.org/10.1016/j.mulfin.2004.03.001

Ferri, M. G., \& Jones, W. H. (1979). Determinants of financial structure: A new methodological approach. Journal of Finance, 34(3), 631-644. http://dx.doi.org/10.1111/j.1540-6261.1979.tb02130.x

Fosberg, R. H. (2012). Capital structure and the financial crisis. Journal of Finance and Accountancy, 11, 46-55.

Ibrahimo, M. V., \& Barros, C. P. (2009). Relevance or irrelevance of capital structure?. Economic Modelling, 26(2), 473-479. http://dx.doi.org/10.1016/j.econmod.2008.10.003

Jensen, M. C., \& Meckling, W. H. (1976). Theory of the firm: Managerial behavior, agency costs and ownership structure. Journal of Financial Economics, 3(4), 305-360. http://dx.doi.org/10.1016/0304-405X(76)90026-X

Kim, W. S., \& Sorensen, E. H. (1986). Evidence on the impact of the agency costs of debt on corporate debt policy. Journal of Financial and Quantitative Analysis, 21(2), 131-144. http://dx.doi.org/10.2307/2330733

Kraus, A., \& Litzenberger, R. H. (1973). A state-preference model of optimal financial leverage. The Journal of Finance, 28(4), 911-922. http://dx.doi.org/10.1111/j.1540-6261.1973.tb01415.x

Lim, Y. (2004). Sources of Corporate Financing and Economic Crisis in Korea: Micro-evidence. In Governance, Regulation, and Privatization in the Asia-Pacific Region, NBER East Asia Seminar on Economics, University of 
Chicago Press, 12, 159-184. http://dx.doi.org/10.7208/chicago/9780226386966.003.0007

Miller, M. H. (1977). Debt and taxes. The Journal of Finance, 32(2), 261-275. http://dx.doi.org/10.1111/j.1540-6261.1977.tb03267.x

Modigliani, F., \& Miller, M. H. (1958). The cost of capital, corporation finance and the theory of investment. The American Economic Review, 48(3), 261-297.

Modigliani, F., \& Miller, M. H. (1963). Corporate income taxes and the cost of capital: a correction. The American Economic Review, 53(3), 433-443.

Myers, S. C. (1984). The capital structure puzzle. The Journal of Finance, 39(3), 574-592. http://dx.doi.org/10.1111/j.1540-6261.1984.tb03646.x

Myers, S. C., \& Majluf, N. S. (1984). Corporate financing and investment decisions when firms have information that investors do not have. Journal of Financial Economics, 13(2), 187-221. http://dx.doi.org/10.1016/0304-405X(84)90023-0

Ozkan, A. (2001). Determinants of capital structure and adjustment to long run target: evidence from UK company panel data. Journal of Business Finance and Accounting, 28(1-2), 175-198. http://dx.doi.org/10.1111/1468-5957.00370

Pattani, A., \& Vera, G. (2011). Going public: UK's company use of capital markets. Retrieved from http://www.bankofengland.co.uk/publications/Documents/quarterlybulletin/qb110403.pdf

Rajan, R. G., \& Zingales, L. (1995). What do we know about capital structure? Some evidence from international data. The Journal of Finance, 50(5), 1421-1460. http://dx.doi.org/10.1111/j.1540-6261.1995.tb05184.x

Titman, S., \& Wessels, R. (1988). The determinants of capital structure choice. The Journal of Finance, 43(1), 1-19. http://dx.doi.org/10.1111/j.1540-6261.1988.tb02585.x

Voutsinas, K., \& Werner, R. A. (2011). Credit supply and corporate capital structure: Evidence from Japan. International Review of Financial Analysis, 20(5), 320-334. http://dx.doi.org/10.1016/j.irfa.2011.05.002

Zarebski, P., \& Dimovski, B. (2012). Determinants of capital structure of A-REITS and the global financial crisis. Pacific Rim Property Research Journal, 18(1), 3-19. http://dx.doi.org/10.1080/14445921.2012.11104347 